\title{
THE EFFECTIVENESS OF ENVIRONMENTAL LEARNING MODEL ON STUDENTS' MOTIVATION AND LEARNING OUTCOMES
}

\author{
Warda Murti' ${ }^{1}$, Sri Maya ${ }^{2}$ \\ 1,2Maros Muslim University \\ 1,2Jalan dr. Ratulangi No.62 Maros \\ Email: wardamurti@umma.ac.id¹, srimaya@umma.ac.id²
}

\begin{abstract}
:
This study aims to determine the effectiveness of the environmental learning model on the students' motivation and learning outcomes in Biology Education Study Program at Muslim University of Maros. This research is a quantitative study using a pre-experimental design with One-Shot Case. The class was taught online using Google Classroom application. The subjects in this study were the fourth-semester students of Biology Education Study Program consisting of 16 students in the Natural Resource Management course. The instruments used in this study were questionnaires and tests. The data was then analyzed using descriptive and inferential statistics. The findings indicated that the environmental learning model effectively increased students' motivation and learning outcomes with average scores of $84.73 \%$ and $77.33 \%$, respectively.
\end{abstract}

\begin{abstract}
Abstrak:
Penelitian ini bertujuan untuk mengetahui keefektifan model pembelajaran environmental learning terhadap motivasi dan hasil belajar mahasiswa Program Studi Pendidikan Biologi Universitas Muslim Maros. Penelitian ini merupakan penelitian kuantitatif dengan menggunakan pre-eksperimen dengan desain One Shot Case. Kelas diajarkan secara online menggunakan aplikasi Google Classroom. Subjek dalam penelitian ini adalah mahasiswa semester IV Program Studi Pendidikan Biologi yang terdiri dari 16 mahasiswa pada mata kuliah Pengelolaan Sumber Daya Alam. Instrumen yang digunakan dalam penelitian ini adalah angket dan tes. Data tersebut kemudian dianalisis menggunakan statistik deskriptif dan inferensial. Hasil penelitian menunjukkan bahwa model pembelajaran lingkungan efektif dalam meningkatkan motivasi dan hasil belajar siswa dengan nilai rata-rata masing-masing $84,73 \%$ dan $77,33 \%$.
\end{abstract}

\section{Keywords:}

Environmental Learning, Motivation, Learning Outomes

How to Cite: Murti, W. \& Maya, S. (2021). The Effectiveness of Environmental Learning Model on Students' Motivation and Learning Outcomes. Lentera Pendidikan : Jurnal Ilmu Tarbiyah dan Keguruan, 24(2), 255-263. https://doi.org/10.24252/lp.2021v24n2i8.

\section{INTRODUCTION}

Biology is a branch of science with abstract material. Still, with a practicum in each material, abstract things can become real for students, but the emergence of the covid 19 pandemics in early 2020 requires us to do online learning, so lab work is impossible. It encourages the creativity of a lecturer to use an effective learning model for these 
conditions. During online learning by using the Google Classroom application in Muslim University of Maros, especially students in the Biology Education study program encountered some difficulties. Most students complained about bad internet connection. Sometimes students could not take lessons on time. Poor internet connection makes their motivation to take part in learning reduced and will impact learning outcomes. Therefore, lecturers must be more creative in providing learning methods to increase students' enthusiasm for learning even though they cannot meet directly in class.

Several researchers (Amini, 2015; Khoiriyah, 2015; Rohmah, 2014; Suryabrata, 2002; Nomura, 2009; Ozden, 2008; Sardiman, 1994) had studied environmental learning models. They examined the environmental learning model applied in the learning and teaching process. One research examined the environmental learning model to increase students' awareness of and care about the environment. Another study was to observe how education managers in Indonesia applied the environmental learning approach. Segara (2015) stated that the environmental learning model is one of the solutions to the environmental-based learning model developed to gain more experience related to the surrounding environment. The students can obtain the materials presented by the lecturers in real terms by utilizing the surrounding environment even though it is not carried out in the laboratory. In addition, the surrounding environment is the learning facility that can be optimized in achieving the teaching and learning process and producing quality education (Rusman, 2011; Khoiriyah, 2015).

According to Prabawani, Hanika, Pradhanawati, \& Budiatmo (2017), the environment as a learning tool for students can optimize its benefits in the teaching and learning process to enrich students' learning materials and activities on campus. In addition, other researchers (Prasetiyo \& Suyanto, 2013; Afandi, 2013; Suduc, Bizoi, \& Gorghiu, 2014; Barquet, 2015) also stated that the environment has a vital role, namely a source of student learning and at the same time as a facility and infrastructure. The environment surrounding is from learning facilities that can be optimized in achieving the teaching and learning process is an environment that sets aside things that students can observe.

In a learning activity, the steps contained in the specified learning model greatly affect the course of the learning process. Therefore, lecturers must understand the learning steps well (Bahri, 2016). The steps of the environmental learning model adopted from Dayanti (2018) are as follows:

Table 1. Steps of the Environmental Learning Model

\begin{tabular}{lll}
\hline \multicolumn{1}{c}{ Lecturers } & \multicolumn{1}{c}{ Students } \\
\hline a. Lecturers observe the needs of the a. $\begin{array}{l}\text { Students describe and briefly } \\
\text { describe the environment in which } \\
\text { learning environment; }\end{array}$ & $\begin{array}{l}\text { they live; } \\
\text { b. Lecturers arrange themes and } \\
\text { teaching materials according to the } \\
\text { student environment; }\end{array}$ & $\begin{array}{l}\text { Students and lecturers carry out } \\
\text { teaching and learning activities by } \\
\text { observing the environmental } \\
\text { conditions around students; }\end{array}$ \\
$\begin{array}{l}\text { c. The lecturers ask students to describe } \\
\begin{array}{l}\text { and briefly describe the environment } \\
\text { in which they live; }\end{array}\end{array}$ \\
\hline
\end{tabular}


d. Lecturers and students carry out teaching and learning activities by utilizing the surrounding environment;

e. Lecturers deliver teaching materials;

f. Lecturers include various issues related to the environment in teaching materials;

g. Lecturers embrace students to recall their mistakes towards the environment;

h. Lecturers and students evaluate learning activities. c. Students listen to the teaching material delivered by the Lecturer;

d. Students reflect on their mistakes in the environment;

e. Students take the test;

f. Students and lecturers evaluate learning activities.

Each learning model has its advantages and disadvantages. Because of that, the classification is based on the needs of students and the preparation of lecturers. Oemar (2011) stated that the advantage of using the environmental learning mode was that students met with the natural surroundings to understand the material. The environment can be used at any time, adjusted to the type of material discussed. No budget is needed because everything is already available in nature. In addition, Izzati, Hindarto, \& Pamelasari (2013) stated that students' learning motivation increased with varied learning resources and a unique and unusual learning atmosphere. A relaxed and comfortable learning atmosphere, making students not bored during teaching and learning activities, students can be free to develop and build their understanding. Meanwhile, not all materials are suitable for applying this model, with differences in environmental conditions in various regions, allowing for seasonal changes so that environmental conditions can change. Motivation is the result of several processes whose impact causes enthusiasm and persistence in achieving certain goals (Darmayanti \& Wibowo, 2014).

There are three important elements of building motivation. They are motivation beginning with creating change in a person, motivation starting with the emergence of changes in behavior, and motivation formed of the purpose of life (Taufiq, Amalia, \& Leviana, 2016). Learning outcomes are the results achieved by students after carrying out learning activities. These results describe the mastery of knowledge and skills of students and are written in numbers with tests that are used as indicators of success (Widiyanti, Indriyanti, \& Ngabekti, 2015).

Various factors affect student learning outcomes. One of the most influential factors is the provision of effective and varied learning models. Each student has a different learning style. Therefore the selection of learning models and strategies must be adjusted to their learning style. Another factor is the interest and motivation of students who encourage them to achieve learning goals and get good results based on the results (Landriany, 2014). Slamet (2010) stated that other factors are deliberately designed and manipulated, such as learning materials. Lecturers give lessons is a very influential factor in the achievement of learning outcomes. Thus, learning outcomes are the results obtained by students after going through learning by giving tests as a measure of success. 
Based on the preliminary study, the researchers are interested in conducting a research entitled The Effectiveness of the Environmental Learning Model on Students' Motivation and Learning Outcomes. The objectives of this study are to find out how the effectiveness of the environmental learning model on students' learning motivation and learning outcomes. The findings of this research are expected to provide benefits for the students and lecturers in applying the environmental learning model.

\section{RESEARCH METHOD}

This research was carried out in Biology Education Study Program at Muslim University of Maros. The research subjects were the fourth-semester students of Biology Education Study Program of 2020/2021 academic year who took the Natural Resource Management course consisting of 16 students. The type of research used is quantitative research with the Experimental method, where the design is One-Shot Case (Sudijono, 1998). The instruments used were questionnaires and tests. The questionnaire form was close-question, and the test form was multiple-choice with 25 items.

The validity test of the questionnaire in this study used the Pearson product-moment validity test. Its principle is collaborating between each questionnaire item score with the total score of respondents' answers and reliability testing. In this study, reliability testing used SPSS assistance with Cronbach's Alpha method. The questionnaire is reliable if the Cronbach alpha value is higher than 0.6 (Sutrisno, 1997). The test was analyzed using descriptive statistics. It is intended to describe the distribution characteristics of students' learning outcomes in the experimental class and control class. This analysis includes the high and lowest value, average, and standard deviation. Inferential statistics are statistics used to analyze sample data, and the results are generalized (differentiated) to the population in which the sample is taken for hypothesis testing purposes (Suharjono, 2009; Suyadi, 2013).

Data about students' learning outcomes were analyzed descriptively. Descriptive learning outcomes data are described in the frequency distribution table so that students' achievement will be seen at certain scores. The criteria used to determine the category of students' learning outcomes in this study referred to the scale used in lectures at Biology Education Study Program, Muslim University of Maros as shown in Table 2 as follow:

Table 2. Criteria for Learning Outcomes Level

\begin{tabular}{cc}
\hline Mastery Level & Category \\
\hline $85-100$ & Very high \\
$70-84$ & High \\
$56-69$ & Medium \\
$45-55$ & Low \\
$0-44$ & Very low \\
\hline
\end{tabular}

Based on the scale learning outcomes used in Biology Education Study Program at Muslim University of Maros, the students passed the medium category, which is 69. It means that the students pass on the Natural Resource Management course. The data of students' learning motivation were also analyzed descriptively. The data was obtained 
from the questionnaire given to students after learning ended. The criteria used to determine the category of students' response scores in this study refer to the scale of Sudjana (2005), as shown in table 3:

Table 3. Criteria for Students' Response Scores

\begin{tabular}{cc}
\hline Students' Responses (\%) & Category \\
\hline $75 \% \%$ PRM $100 \%$ & Very good \\
$50 \% \% \mathrm{PRM}<75 \%$ & Good \\
$25 \% \% \mathrm{PRM}<50 \%$ & Less \\
$0 \% \% \mathrm{PRM}<25 \%$ & Very less \\
\hline
\end{tabular}

Note: PRM is the percentage scores of students' responses on statement items.

The criteria for students' response scores on the t-test are intended to test research hypotheses regarding differences in students' learning motivation after participating in environmental learning at Biology Education Study Program, Muslim Maros University. Ttest was analyzed using SPSS by Windows 2016 program. The significant level used was = 0.05 with the criterion of rejecting $\mathrm{H} 0$ if $t$-test $\geq \mathrm{t}$-table and $\mathrm{H} 0$ is accepted if $\mathrm{t}$-test $\leq \mathrm{t}$-table, the value of sig $\leq \alpha$ then reject $\mathrm{H} 0$.

\section{RESULTS AND DISCUSSION}

Based on the analysis results of students' learning outcomes, it was obtained that the test scores of students' learning outcomes after the environmental learning model were applied were quite varied. The value of the statistical table of students' learning outcomes tests can be seen in Table 4 below:

Table 4. Value of Student Learning Outcomes Statistics

\begin{tabular}{cc}
\hline Statistics & Statistical Value \\
\hline Subject & 16 \\
\hline Ideal score & 100 \\
\hline Average & 77.31 \\
\hline The highest score & 100 \\
\hline Lowest score & 53.50 \\
\hline Score range & 48.50 \\
\hline Median & 77.33 \\
\hline Mode & 70 \\
\hline Standard deviation & 10.65 \\
\hline Variance & 113.37
\end{tabular}

Based on table 4, it can be concluded that many students who have completed this environmental material consisting of ten students or $84.37 \%$ completed and six students have not completed or have not met a completeness score of seventy. Meanwhile, the average of students' learning outcomes was 78.31 or is in the high category. Furthermore, the students' responses after the questionnaires were distributed showed that the percentage of students' responses was $83.72 \%$ or was in the very good category. 
Table 5. Test Results One-Sample Test

\begin{tabular}{lccl}
\hline Source & t-count & p-value & Description \\
\hline Learning Outcomes Test & 40.503 & 0.000 & Ho rejected \\
\hline
\end{tabular}

Based on the summary of the results of data analysis in table 5, the score of t-count was 40.503 with the $p$-value of $0.000<\alpha=0.05$. There are differences in students' learning outcomes after being taught by applying the environmental learning model to the Biology Education Study Program. Furthermore, table 6, which measures the results of the onesample test, can be seen in the following table:

Table 6. Test Results One-Sample Test

\begin{tabular}{llll}
\hline Source & t-count & p-value & Description \\
\hline Learning Motivation & 42.110 & 0.000 & H0 is rejected \\
\hline
\end{tabular}

Table 6 shows differences in students' learning motivation after being taught by applying the environmental learning model to the biology education study program for the Natural Resource Management course. Students' learning outcomes show in table 3 that the average of students' learning outcomes in the fourth semester of Biology Education Study Program within the scope of Muslim University of Maros in the natural resource management course was 78.31. Ten students, or $84.37 \%$, were declared complete with the final score of 70 . Meanwhile, six students, or $15.63 \%$, were not declared complete because they obtained a final score under 70. Based on the results of observations of students' responses through questionnaire data collection, it was found that the percentage value was $84.73 \%$. Based on the results of the students' response questionnaire, the lowest percentage was $79.13 \%$ while the highest was $93.5 \%$. The lowest percentage of students' responses was when they were asked whether their friends suggested using the environmental learning model. At the same time, the highest was obtained when students were asked to respond to the learning model. Based on the students' response questionnaires, data obtained that the environmental learning model was very useful in Biology learning process.

From the learning results by applying the environmental learning model using Google classroom media, the percentage of students' responses was $89.38 \%$ and $88.75 \%$. In this study, it can be said that the learning model can support learning in the Natural Resource Management course coupled with the help of Google classroom media. To print the required documents, they can access them through their respective classrooms. In addition, students are also facilitated to obtain announcements given by lecturers quickly (real-time) so that they become effective and efficient in terms of time.

The application of the environmental learning model obtains higher learning outcomes and motivates students to learn comparing before learning with this model. The students are brought directly into the concrete world so that they experience the material being taught. Amini (2015) stated that the application of this model does not require a fee because everything has been provided by nature. Students' learning motivation will also increase because students experience a different learning atmosphere than usual. 
The effect of learning motivation on learning achievement is the tendency of students to carry out learning activities that are driven by a desire to achieve the best possible achievement or learning outcomes (Rahmayati, 2016; Putriana, 2013). Motivation always underlies and influences every effort and activity of a person to achieve the desired goal. Students who always have good and strong motivation will enlarge their efforts and activities in achieving high achievements. Based on researches (Listiawati, 2013; Maesaroh, 2013), those who lose motivation in learning will have an unfavorable impact on their learning achievement. The significant results of the learning model's influence on students' learning motivation can be used as a benchmark to increase their learning motivation further to achieve optimal learning achievement. In addition to students, lecturers must also manage appropriately to foster students' motivation to learn.

The use of the environmental learning model is also adapted to the needs of the student environment (Amini, 2015). The arrangement and steps carried out are almost the same as the conventional model. Only in this model must educators involve material about the environment. Based on the description above, the authors can conclude that the environmental learning model is an environment-based learning model with learning steps that include preparing teaching themes with the environment, discussing problems related to the environment, giving tests, and evaluating learning. If these steps are implemented, students will have more experience with the environment.

Another advantage of using the environmental learning model is that students are not bored with what they are learning. Students gain knowledge and understanding by observing themselves and fostering students' love for the environment. Thus, it can be said that with this model, students will better understand themselves and their environment. In addition, students will also have a love for the environment around them. However, the environmental learning model also has weaknesses. It includes requiring more energy and can only be used in some learning materials. In line with research conducted by Listiawati and Maesaroh, each learning model must have different strengths and weaknesses. It is classified based on student needs and lecturer readiness. This learning model can be used as a reference for educators to be applied in learning so that students get new experiences in learning and increase their learning motivation.

\section{CONCLUSION}

Based on the results and discussion of this research, it can be concluded that the environmental learning model effectively increases motivation and learning outcomes of the Natural Resource Management course of the fourth-semester students in Biology Education Study Program, Muslim University of Maros. The findings indicated that $\mathrm{H} 0$ was rejected. Besides, the percentage of students' motivation $(84.73 \%)$ and the average score (77.33\%) of students' learning outcomes were high categories. 


\section{REFERENES}

Afandi, R. (2013). Integrasi Pendidikan Lingkungan Hidup melalui Pembelajaran IPS di Sekolah Dasar sebagai Alternatif Sekolah Dasar. Jurnal Pedagogia, 2(1), 98-108. https://doi.org/10.21070/pedagogia.v2i1.50.

Amini, R. (2015). Outdoor Based Environmental Education Learning and Its Effect in Caring Attitude Toward Environment. Jurnal Pendidikan IPA Indonesia, 4(1), 4347. https://doi.org/10.15294/jpii.v4i1.3500.

Bahri, S. (2016). Komparasi Kemandirian Siswa Berlandaskan Jiwa Entrepreneurship di SMK N 2 Mataram. Jurnal Social, 15(1), 33-51. https://doi.org/10.21831/socia.v13i1.9902.

Barquet, K. (2015). Building a bioregion through transboundary conservation in Central America. Norwegian Journal of Geography, 69(5), 265-276. https://doi.org/10.1080/00291951.2015.1087421.

Darmayanti, S. E., \& Wibowo, U. B. (2014). Evalusiasi Program Pendidikan Karakter di Sekolah Dasar Kabupaten Kulon Progo. Jurnal Prima Edukasia, 2(2), 223-234. https://doi.org/10.21831/jpe.v2i2.2721.

Dayanti, N. (2018). Penerapan Pendekatan Environmental Learning Pada Tema Sehat Itu Penting Untuk Meningkatkan Hasil Belajar Mahasiswa Kelas V Min 11 Banda Aceh [UIN Ar-Raniry Banda Aceh]. https://repository.ar-raniry.ac.id/id/eprint/3316.

Izzati, N., Hindarto, N., \& Pamelasari, S. D. (2013). Pengembangan Modul Tematik dan Inovatif Berkarakter pada Tema Pencemaran Lingkungan untuk Siswa Kelas VII SMP. Jurnal Pendidikan IPA Indonesia, 2(2), 183-188. https://doi.org/10.15294/jpii.v2i2.2721.

Khoiriyah, L. F. (2015). Implementasi Model Environmental Learning dalam mewujudkan Kepedulian Lingkungan pada Mahasiswa IV SDN Dinoyo2 Malang [UIN Maulana Malik Ibrahim Malang]. http://etheses.uin-malang.ac.id/6790/1/11140133.pdf.

Landriany, E. (2014). Implementasi Kebijakan Adiwiyata dalam Upaya Mewujudkan Pendidikan Lingkungan Hidup di SMA Kota Malang. Jurnal Kebijakan Dan Pengembangan Pendidikan, 2(1), 82-88. https://doi.org/10.22219/jkpp.v2i1.1739.

Listiawati, N. (2013). Pelaksanaan Pendidikan untuk Pembangunan Berkelanjutan Oleh Beberapa Lembaga. Jurnal Pendidikan Dan Kebudayaan, 19(3), 430-450. https://media.neliti.com/media/publications/120796-none-acfb4625.pdf.

Maesaroh, S. (2013). Peranan Metode Pembelajaran Terhadap Minat dan Prestasi Belajar Pendidikan Agama Islam. Jurnal Kependidikan, 1(1). https://doi.org/10.24090/jk.v1i1.536.

Nomura, K. (2009). A Perspective on Education for Sustainable Development: Historical Development of Environmental Education in Indonesia. International Journal of $\begin{array}{lll}\text { Educational Development, 29(6), 621-627. } & \end{array}$ https://doi.org/10.1016/j.ijedudev.2008.12.002.

Oemar, H. (2011). Curriculum and Education. Bandung: PT Bumi Aksra.

Ozden, M. (2008). Environmental Awareness and the Attitudes of Student teachers: An empirical research. International Research in Geographical \& Environmental Education, 17(1), 40-55. https://doi.org/10.2167/irgee227.

Prabawani, B., Hanika, I. M., Pradhanawati, A., \& Budiatmo, A. (2017). Primary Schools EcoFriendly Education in The Frame of Education for Sustainable Development. International Journal of Environmental \& Science Education, 12(4), 607-616. http://www.ijese.net/makale/1831.html. 
Prasetiyo, W. H., \& Suyanto, T. (2013). Strategi Pendidikan Karakter Peduli Lingkungan melalui Program Kampung Hijau Di Kampung Margorukun Surabaya. Jurnal Kajian Moral Dan Kewarganegaraan, 2(1), 302-316. https://jurnalmahasiswa.unesa.ac.id/index.php/jurnal-pendidikankewarganegaraa/article/view/3721/1978.

Putriana, N. (2013). Pengaruh Lingkungan Keluarga dan Lingkungan Kampus Terhadap Prestasi Belajar Mahasiswa Pada Mata Pelajaran Akuntansi di Kelas XI IPS SMA Pasundan. Jurnal Pendidikan Akuntasi Dan Keuangan, 4(1). https://doi.org/10.17509/jpak.v3i1.15383.

Rahmayati, V. (2016). Pengaruh Minat Belajar Mahasiswa Dan Persepsi Atas Upaya Dosen Dalam Memotivasi Belajar Mahasiswa Terhadap Prestasi Belajar Bahasa Indonesia Mahasiswa SMP Di Depok. Jurnal SAP, 1(2). https://doi.org/10.30998/sap.v1i2.1027.

Rohmah, L. (2014). Implementasi Kurikulum Berbasis Education for Sustainable Development (ESD) di SD IT Internasional Luqman Hakim Yogyakarta. Al-Bidayah: Jurnal Pendidikan Dasar Islam, 6(2), 217-234. https://doi.org/10.14421/albidayah.v6i2.139.

Rusman. (2011). Model- Model Pembelajaran. Jakarta: Raja Grafindo Persada.

Sardiman, A. M. (1994). Interaksi dan Motivasi Belajar Mengajar. Jakarta: Raja Grafindo Persada.

Segara, N. B. (2015). Education for Sustainable Development (ESD) Sebuah Upaya Mewujudkan Kelestarian Lingkungan. Sosio Didaktika: Social Science Education Journal, 2(1), 22-30. https://doi.org/10.15408/sd.v2i1.1349.

Slamet. (2010). Belajar dan Faktor-Faktor yang Mempengaruhinya. Jakarta: Rineka Cipta.

Sudijono, A. (1998). Pengantar Evaluasi Pendidikan. Jakarta: Raja Grafindo Persada.

Sudjana. (2005). Metode Statistik. Bandung: Tarsito.

Suduc, A. M., Bîzoi, M., \& Gorghiu, G. (2014). Sustainable Development in Romania in Preschool and Primary Education. Procedia-Social and Behavioral Sciences., 11871192. https://doi.org/10.1016/j.sbspro.2014.01.367.

Suharjono. (2009). Penelitian Tindakan Kelas dan Tindakan Sekolah. Malang: Cakrawala Indonesia dan IP3UM.

Suryabrata. (2002). Proses Pembelajaran di Sekolah. Jakarta: Rineka Cipta.

Sutrisno, H. (1997). Metodologi Research. Yogyakarta: UGM.

Suyadi. (2013). Panduan Penelitian Tindakan Kelas. Yogyakarta: Diva Press.

Taufiq, M., Amalia, A. V., \& Leviana, A. (2016). Design of Science Mobile Learning of Eclipse Phenomena with Conservation Insight Android-based APP Inventor 2. Jurnal Pendidikan IPA Indonesia, 5(2), 291-298. https://doi.org/10.15294/jpii.v5i2.7375.

Widiyanti, F., Indriyanti, D. R., \& Ngabekti, S. (2015). Literacy-based Natural Science Teaching Set Toward the Students' Learning Activities and Outcomes on The Topic of The Interaction of Living Organism and Environment. Jurnal Pendidikan IPA Indonesia, 4(1). https://doi.org/10.15294/jpii.v4i1.3496. 